\title{
Dommedagsanden - Australiens bud på Verdens storste rapand
}

Af geolog Morten L. Hjuler

En kødædende kæmpeand med et næb på størrelse med et hestehoved og en kampvægt på to en halv struds... Det er skræmmende! Heldigvis er den uddød!

Vi skriver anno 2008, Sydney, Australien. Det er flere minutter siden kænguruflokken pludseligt forsvandt, og ænderne lettede fra søens smågrumsede vand. Parken er blevet helt stille. Rangerens blik fejer nervøst fra side til under den bredskyggede hat, mens han med skælvende stemme udveksler oplysninger med sine lige så nervøse kolleger andre steder i den store park. Walkie-talkien skratter højlydt. En gammel dame knuger krampagtigt håndtagene på sin mintfarvede rollator, mens adskillige småbørnsfamilier febrilsk pakker rangler, sutter og pixibøger væk og gør klar til opbrud.

Alle ved, det kan ske, men episoder er så sjældne, at ingen tager risikoen alvorligt. Undtagen rangeren; men siden han blev ansat for 5 år siden, har der ikke været sammenstød. Han er ikke tryg ved situationen. Han kæmper for at bevare roen og udveksler et hastigt blik med sin kompagnon bag rattet i evakueringskøretøjet - en forlænget og stærkt pansret Hummer med plads til 16 personer. Det er lige op over, og ikke alle parkgæster er på plads i Hummeren. Det går for langsomt. Han skynder fortvivlet på den gamle dame, som stædigt insisterer på at få rollatoren med.

Endelig! Rollatoren får det sidste puf ind i kabinen. Svage rystelser i jorden akkompagneret af en underligt afdæmpet gungren får rangeren til at vende sig hastigt rundt. Han fryser til is. 11 dommedagsænder er mindre end 100 meter væk og nærmer sig med over $30 \mathrm{~km} / \mathrm{t}$. Den forreste åbner sit enorme næb og gør sig klar til at hugge. Han er paralyseret af de intenst stirrende, ravgule øjne.

Rædselsskrigene inde fra Hummeren vækker ham abrupt til live, og han kaster sig ind på passagersædet og får smækket døren. I allersidste øjeblik. Sekundet efter hugger næbbet, og trykker taget flere centimeter ind i kabinen. De øvrige dommedagsænder går rasende til angreb med næb og klør, og får næsten væltet Hummeren ved sammenstødet. Godt den vejer 8 tons. Rangeren ved rattet trykker rystet speederen i bund og får køretøjet op i fart, altimens kæmpefuglene går amok udenfor.

Øjeblikke senere har den ramponerede Hummer bragt sine chokerede passagerer uden for dommedagsændernes rækkevidde. Det gik godt denne gang...

Sådan kunne en ganske almindelig søndag eftermiddag have udspillet sig i Australien, hvis Bullockornis planei havde eksisteret i dag... Det gør den heldigvis ikke!

\section{Tordenfuglene}

Bullockornis planei tilhører familien Dromornithidae, en gruppe af gigantiske, strudselignende fugle som huserede i Australien for 25 millioner år siden og frem til for 26.000 år siden. Familiens største medlem, Dromornis stirtoni, var med 3 meters højde og en vægt på over 500 kg tillige den største fugl, som nogensinde har levet. Ikke underligt at familien kærligt omtales som tordenfugle.

I lighed med strudsen kunne disse kæmpefugle ikke flyve, og traditionelt har man opfattet tordenfuglene og strudsen som nært beslægtede. Slægtsskabet har dog været svært at eftervise, for selvom de første tordenfuglefossiler blev beskrevet tilbage i 1839, har det været småt med vidnesbyrd om kraniet, som traditionelt er tætpakket med informationer om dyrets levevis og essentielt for udredningen af taksonomiske relationer. Alle forsøg på at identificere tordenfuglenes slægtninge har på sin vis været hovedløs gerning! Indtil for nylig, hvor flere kranier af den 15 millioner år gamle Bullockornis planei dukkede op..

\section{En underlig and}

Fundet af kranierne betød, at strudsen blev bedt om at stikke hovedet i busken, for meget tydede på, at tordenfuglene var nærmere beslægtet med ænder og gæs. Og ikke nok med det! Det imponerende kranium (eller rettere, det imponerende næb) kombineret med magtfulde kæbemuskler indikerer, at $B$. planei ikke kun nippede til salatblade - om overhovedet. Denne 2,5 meter høje og $300 \mathrm{~kg}$ tunge tordenfugl fra Miocæn var fuldt udstyret med det nødvendige værktøj til at nedlægge store byttedyr eller forgribe sig på ådsler.

Sammenlignet med nutidens fredelige ænder var $B$. planei et skræmmende monster, hvilket har afstedkommet mindre flatterende øgenavne såsom dommedagsanden, djævleanden og fuglen fra helvede. Det småtrivielle an(d)egalleri er i sandhed blevet udvidet med en drabelig fætter. 